\title{
BIOTURBATIONAL STRUCTURES IN THE NORTH ATLANTIC: NEW APPROACHES FOR STUDYING CORES
}

FU*, Shaoping, Institut und Museum für Geologie und Paläontologie der Universität

Kiel, Olshausenstrasse 40, 2300 Kiel, Germany; WERNER, Friedrich, Institut und Museum für Geologie und Paläontologie der Universität Kiel, Olshausenstrasse 40, 2300 Kiel, Germany

General environmental correlation, established for trace fossils, is hard to apply to modern sediment cores, for which environmental factors can be measured directly - at least with regard to the top layers. Reasons for this difficulty are obvious: (1) Outcrop volume is limited by the core diameter. (2) Biogenic structures are hard to see, because they have not yet been "developed" by diagenetic processes. (3) Cores are traditionally studied in vertical cuts, in which search patterns parallel to bedding plane - typical for deep-sea environment - are poorly expressed.

Therefore cores from the North Atlantic were studied not only by traditional X-ray radiography (both vertical and horizontal cuts), but by computer tomography (CT), which renders series of sections parallel to the bedding plane, as well as a threedimensional picture, without destroying the valuable core.

On the Iceland-Faeroe Ridge, the distribution of ichnocoenoses appears to be largely controlled by microenvironments in connection with local channel systems and their lateral migration. In a local, ridge-parallel channel system at the southern slope, a core from the NE flank shows a vertical alternation of Zoophycos, Trichichnus, and Planolites communities correlating with fluctuations of $\mathrm{CaCO}_{3}$ and the fraction $>63 \mu \mathrm{m}$. In contrast to this, on the opposite slope, sediments are uniform and dominated by Scolicia. On the colder N slope of the ridge, topography is more uniform and the water motion is sluggish. The characteristic and dominant ichnogenus is Chondrites. On top of the ridge the sediment cover becomes very thin, contains large amounts of dropstones, but still Chondrites is dominant. 